\section{Jagoda Balaban', Vesna Gajanin ${ }^{2}$}

\section{Alergijska oboljenja pacijenata liječenih u Kliničkom centru Banjaluka: rezultati kožnog prick testa u desetogodišnjem periodu}

\begin{abstract}
APSTRAKT
Uvod. Aeroalergeni su najčešći uzroci alergije. Oni uključuju polene, grinje kućne prašne, životinjsku dlaku i druge životinjske produkte. Cilj našeg istraživanja je ustanoviti koji su aeroalergeni odgovorni za alergijska oboljenja bolesnika testiranih u Kliničkom centru Banjaluka od 2001. do 2010. godine.

Metode. $U$ ovo retrospektivno istraživanje su uključena 4003 pacijenta uzrasta kasne adolescencije i odrasle dobi. Veći broj ispitanika (63,5\%) bio je ženskog pola. Odgovor na aeroalergene ocijenjen je kožnim prick testovima.

Rezultati. Kod pacijenata su najčešće bili dijagnostikovani rinitis (40,8\%), a zatim slijede dermatitis (27,6\%), različite alergijske dijagnoze (16,1\%) i astma (15,5\%). Više od trećine (38,3\%) in je odgovorilo pozitivno na najmanje jedan alergen. Grupa sa rinitisom je imala najveći broj pozitivnih testova na grinju kućne prašine (Dermatophagoides pteronyssinus) (24,1\%) i polene korova (18,3\%), zatim na polene trava (15,2\%), a najmanje na polene drveća (8,2\%). Mali broj pacijenata je pozitivno reagovao na alergene životinjske dlake (1,5\%), perja (2,6) i bubašvabe $(2,8 \%)$. Grupa ispitanika sa različitim dijagnozama je imala najmanje pozitivnih reakcija. Nije bilo statistički značajne razlike između grupa testiranih na bubašvabu (Blatella germanica), perje i životinjsku dlaku. lako su pacijenti ženskog pola brojniji, kod muškaraca su svi alergeni češće pozitivni nego kod žena.

Zaključak. Više od trećine testiranih pacijenata ima alergijski rinitis. Grinja kućne prašine (Dermatophagoides pteronyssinus) i poleni korova su najčešći aeroalergeni u svim ispitivanim grupama.
\end{abstract}

\section{KLJUČNE RIJEČI}

aeroalergeni, kožni prick test, rinitis, astma, dermatitis

DOI: $10.7251 / S M D 1201020 B$

(Scr Med 2012;43:2O-4)

\author{
1 Klinika za kožne i polne bolesti, \\ Univerzitetski klinički centar, \\ Banjaluka \\ 1 Depatrment of Dermatovene- \\ rology, University Clinical Center, \\ Banja Luka \\ 2 Zavod za anatomiju, Medicinski \\ fakultet, Banjaluka \\ 2 Department of Anatomy, Faculty of \\ Medicine, University of Banja Luka

\section{Correspondence} \\ Dr Jagoda Balaban, Klinika za kožne \\ i polne bolesti, Univerzitetski Klinički \\ centar, 12 beba bb, 78000 Banjaluka, \\ Republika Srpska \\ Bosna i Hercegovina \\ Tel. +38765 620-212 \\ Email: jagoda.balaban@yahoo.com
}

Submitted: January 15, 2012 Accepted: April 2, 2012
Aeroalergeni koji se navode kao najčešći uzroci alergijskih bolesti su poleni, grinje kućne prašine, animalna dlaka i produkti životinjskog porijekla. ${ }^{1}$ Poleni koji izazivaju alergiju uglavnom potiču iz trava, korova i drveća. ${ }^{2}$ Grinje Dermatophagoides pteronyssinus i Dermatophagoides farinae su najčešći i najznačajniji alergeni kućne prašine u svijetu. ${ }^{3}$ Ostali aeroalergeni animalnog porijekla koji se često opisuju kao uzroci respiratorne i kožne alergije potiču od mačke, psa i bubašvabe. ${ }^{4,5}$ Opšte je poznato da je sezonska prevalencija rinitisa i astme (od 10\% do 40\%) veća kod djece i adolescenata nego kod odraslih, ali je perenialni rinitis češći kod odraslih nego kod djece. Prevalencija ovih oboljenja posljednjih nekoliko deceni- ja raste u svim dijelovima svijeta, naročito u Zapadnim zemljama. ${ }^{6}$

S obzirom na gotovo pandemijski rast alergije, ovom problemu posvećuje se mnogo pažnje i brojna istraživanja su provedena u mnogim zemljama (Finska ${ }^{7}$, Španija, Portu$\mathrm{gal}^{8}$, Turska $\left.{ }^{9} \mathrm{i} \operatorname{Iran}^{10}\right)$. U pomenutim radovima se navodi da je glavni alergen grinja kućne prašine (Dermatophagoides pteronyssinus). Rezultati drugih istraživanja ukazuju da su poleni, naročito trava, glavni izvor respiratorne alergije širom svijeta. ${ }^{11-13}$ Do sada nema objavljenih sličnih istraživanja o aeroalergiji i alergijskim oboljenjima kod odraslih pacijenata u kliničkoj, alergološkoj praksi u 
Kliničkom centru Banjaluka ili u nekoj drugoj zdravstvenoj ustanovi u Republici Srpskoj. Postoje, međutim, podaci za Hrvatsku (Cvitanović i sar. ${ }^{14}$ ).

Cilj našeg istraživanja je ustanoviti koji su aeroalergeni odgovorni za alergijske bolesti pacijenata testiranih kožnim prick testom u Klinici za kožne i polne bolesti Kliničkog centra Banjaluka u desetogodišnjem periodu.

\section{Materijal i metode}

Istraživanje je provedeno kao retrospektivna studija u Kliničkom centru Banjaluka. Analizirani su rezultati kožnog prick testa na aeroalergene pacijenata starijih od 16 godina koji su su u periodu od 2001. do 2010. godine testirani u Alergološkoj ambulanti Klinike za kožne i polne bolesti. U istraživanje su uključena 4,003 pacijenata od kojih su 2,543 bile žene, a 1,460 muškarci. Pacijente su na alergološko testiranje upućivali doktori porodične medicine, otorinolaringolozi, dermatolozi ili pulmolozi. Testirani su kožnim prick testom koji se koristi kao siguran i brz metod za skrining atopije i alergije. Za test su korišteni standardizovani alergeni (proizvođač Zavod za alergologiju i imunologiju „Torlak“, Beograd). Test je izvođen, očitavan i interpretiran standardnom metodom za prick testiranje. ${ }^{1}$ Pacijenti su testirani na sedam alergena: grinja kućne prašine, mješavine polena trava, polena korova, polena drveća, perja, životinjske dlake i bubašvabu (Blatella germanica).

Prema uputnim dijagnozama ispitanici su podijeljeni u četiri grupe. U prvu grupu (rinitis), uključeni su pacijenti sa uputnim dijagnozama rinitisa, rinokonjunktivitisa i rinosinusitisa, odnosno oni kod kojih se sumnjalo na alergiju gornjih disajnih puteva. Drugu grupu (astma) činili su pacijenti sa dijagnozama opstruktivnog bronhitisa, astme ili dugotrajnog kašlja, kod kojih se sumnjalo na alergiju donjih disajnih puteva. U treću grupu (dermatitis) su svrstani pacijenti sa dijagnozama kožne alergije: atopijski dermatitis, hronična utrikarija, razni ekcemi. U četvrtu grupu (ostale dijagnoze) su uvršteni pacijenti sa različitim ostalim uputnim dijagnozama kao što su: otitis, konjunktivitis, oni koji su samoinicijativno željeli da budu testirani, kao i pacijenti koji u protokolu nisu imali upisanu uputnu dijagnozu.

Prikupljeni podaci su obrađeni statističkim programom SPSS (verzija 13). U radu je korištena deskriptivna statistika, a za komparaciju procenata pozitivnih nalaza u odnosu na četiri grupe oboljenja multigrupni $\chi^{2}$ test.

\section{Rezultati}

Analizom podatka o mjestu stanovanja utvrđeno je da je najveći broj pacijenata (79\%) iz opštine Banjaluka. Iz Kneževa ih je bilo 6\%, Mrkonjić Grada, Laktaša i Čelinca po $3 \%$, dok je iz ostalih opština bilo manje oboljelih. Više od dvije trećine testiranih $(75,3 \%)$ su bili odrasli, a $24,7 \%$ adolescenti. Nije utvrđena statistički značajna razlika u broju pozitivnih testova između adolescenata i odraslih osoba ( $\chi 2$-test; $p=0,148)$. Prosječno životno doba ispitanika u
Tabela 1. Pozitivni kožni prick testovi prema polu ispitanika

\section{Table 1. Positive skin prick tests by sex of patietns}

\begin{tabular}{|c|c|c|c|}
\hline \multirow{3}{*}{$\begin{array}{l}\text { Alergen } \\
\text { Allergen }\end{array}$} & \multicolumn{2}{|c|}{$\begin{array}{l}\text { Pol } \\
\text { Sex }\end{array}$} & \multirow{3}{*}{$\mathrm{p}$} \\
\hline & $\begin{array}{l}\text { Muški } \\
\text { Male }\end{array}$ & $\begin{array}{l}\text { Ženski } \\
\text { Female }\end{array}$ & \\
\hline & n (\%) & n $\quad(\%)$ & \\
\hline $\begin{array}{l}\text { Dermatophagoides } \\
\text { pteronyssinus }\end{array}$ & $432 \quad(26,9)$ & $531(20,9)$ & $<0,001$ \\
\hline $\begin{array}{l}\text { Mješavina polena } \\
\text { korova } \\
\text { Weed pollen mixture }\end{array}$ & $338 \quad(23,2)$ & $394(15,5)$ & $<0,001$ \\
\hline $\begin{array}{l}\text { Mješavina polena trava } \\
\text { Grass pollen mixture }\end{array}$ & $283(19,4)$ & $324(12,7)$ & $<0,001$ \\
\hline $\begin{array}{l}\text { Mješavina polena } \\
\text { drveća } \\
\text { Tree pollen mixture }\end{array}$ & $143(9,8)$ & $188(7,4)$ & 0,008 \\
\hline $\begin{array}{l}\text { Bubašvaba } \\
\text { Cockroach }\end{array}$ & $59 \quad(4,1)$ & $56(2,2)$ & 0,009 \\
\hline $\begin{array}{l}\text { Mješavina perja } \\
\text { Feather mixture }\end{array}$ & $46(3,2)$ & $56(2,2)$ & 0,077 \\
\hline $\begin{array}{l}\text { Mješavina životinjske } \\
\text { dlake } \\
\text { Animal hair mixture }\end{array}$ & $29(2,0)$ & $33(1,3)$ & 0,117 \\
\hline
\end{tabular}

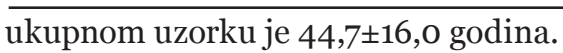

Najveći broj pacijenata $(24,1 \%)$ oba pola je imao pozitivan prick test na Dermatophagoides pteronyssinus i polene korova $(18,3)$, zatim polene trava $(15,1 \%)$ i drveća $(8,2 \%)$, dok ih je manje imalo pozitivnu reakciju na bubašvabu $(2,8 \%)$, perje $(2,6 \%)$ i životinjsku dlaku (1,5\%). Razlika utvrđena u broju pacijenata alergičnih na testirane alergene je statistički značajna ( $\chi 2$-test; $p=0,001)$. Više od trećine $(38,3 \%)$ pacijenata je imalo pozitivan prick test na najmanje jedan alergen.

U ukupnom uzorku bile su zastupljenije osobe ženskog pola $(63,5 \%)$ u odnosu na muški $(36,5 \%)$, ali je broj pozitivnih prick testova na sve alergene izraženiji kod muškaraca nego kod žena. Za grinju kućne prašine, sve mješavine polena i bubašvabu je utvrđena statististički značajna razlika u odnosu na pol (Tabela 1).

Najveći broj pacijenata $(40,8 \%)$ je upućen zbog simptoma alergije gornjeg respiratornog trakta (rinitisa), koji je često udružen sa konjunktivitisom i sinusitisom. Slijedi grupa ispitanika sa kožnom alergijom (27,6\%), zatim grupa sa različitim ostalim dijagnozama $(16,1 \%)$, dok je najmanji broj pacijenata upućen sa simptomima alergije donjeg respiratornog trakta $(15,6 \%)$. Ustanovljena razlika u 
broju ispitanika prema uputnim dijagnozama je statistički značajna ( $\chi 2$-test; $\mathrm{p}<0,001)$. U svim ispitivanim grupama najveći broj pozitivnih testova utvrđen je na Dermatophagoides pteronyssinus, zatim polene korova, trava i drveća, dok je najmanji broj pozitivnih testova bio na dlaku, perje i bubašvabu. Za alergene: Dermatophagoides pteronyssinus, mješavinu polena korova, trave i drveća najveći procenat pozitivnih reakcija je u grupi rinitisa, zatim astme i dermatitisa, a najmanji u grupi sa ostalim dijagnozama (Tabela 2). tivnih prick testova bio na polene korova, zatim trava, najmanji na polene drveća. Aerobiološke i alergološke studije pokazuju da se polenska mapa u Evropi mijenja i da zavisi od stambenih uslova, većih migracija stanovništva i klimatskih promjena. ${ }^{17}$ Postoje istraživanja u kojima su poleni trava navedeni kao glavni uzrok respiratorne alergije ${ }^{18,19}$. Međutim, posljednjih godina, alergija na polene korova je u stalnom porastu u izvjesnim dijelovima Francuske, Italije, Austrije, Hrvatske i Bugarske. ${ }^{16}$ U literaturi smo pronašli

Tabela 2. Pozitivni kožni prick testovi prema grupama ispitanika

Table 2. Positive skin prick tests by groups of patients

\begin{tabular}{|c|c|c|c|c|c|}
\hline \multirow{3}{*}{$\begin{array}{l}\text { Alergen } \\
\text { Allergen }\end{array}$} & \multicolumn{4}{|c|}{$\begin{array}{l}\text { Grupe } \\
\text { Groups }\end{array}$} & \multirow{3}{*}{$\mathrm{p}$} \\
\hline & $\begin{array}{l}\text { Rinitis } \\
\text { Rhinitis }\end{array}$ & $\begin{array}{l}\text { Astma } \\
\text { Asthma }\end{array}$ & $\begin{array}{l}\text { Dermatitis } \\
\text { Dermatitis }\end{array}$ & $\begin{array}{l}\text { Ostale dg. } \\
\text { Other dg.* }\end{array}$ & \\
\hline & n (\%) & $\mathrm{n}(\%)$ & $\mathrm{n}(\%)$ & n (\%) & \\
\hline Dermatophagoides pteronyssinus & $472(28,9)$ & $148(23,9)$ & $228(20,6)$ & $115(17,9)$ & $<0,001$ \\
\hline $\begin{array}{l}\text { Mješavina polena korova } \\
\text { Weed pollen mixture }\end{array}$ & $380 \quad(23,3)$ & $113(18,2)$ & $157(14,2)$ & $82(12,8)$ & $<0,001$ \\
\hline $\begin{array}{l}\text { Mješavina polena trava } \\
\text { Grass pollen mixture }\end{array}$ & $323(19,8)$ & $90 \quad(14,5)$ & $133(12,0)$ & $61(9,5)$ & $<0,001$ \\
\hline $\begin{array}{l}\text { Mješavina polena drveća } \\
\text { Tree pollen mixture }\end{array}$ & $181 \quad(11,1)$ & $47(7,6)$ & $71(6,4)$ & $31(4,8)$ & $<0,001$ \\
\hline $\begin{array}{l}\text { Bubašvaba } \\
\text { Cockroach }\end{array}$ & $54 \quad(3,3)$ & $54(3,3)$ & $36(2,2)$ & $36(2,2)$ & 0,433 \\
\hline $\begin{array}{l}\text { Mješavina perja } \\
\text { Feather mixture }\end{array}$ & $49(3,0)$ & $21(3,4)$ & $25(2,3)$ & $9(1,4)$ & 0,082 \\
\hline $\begin{array}{l}\text { Mješavina životinjske dlake } \\
\text { Animal hair mixture }\end{array}$ & $28(1,7)$ & $10(1,6)$ & $18(1,6)$ & $6(0,9)$ & 0,583 \\
\hline $\begin{array}{l}\text { Najmanje jedan pozitivan allergen } \\
\text { At least one positive allergen }\end{array}$ & $765(46,8)$ & $224(36,1)$ & $358(32,4)$ & $186(28,9)$ & $<0,001$ \\
\hline
\end{tabular}

* Diagnosis

\section{Diskusija}

Ovim istraživanjem smo ustanovili da je rinitis najčešće alergijsko oboljenje kod testiranih pacijenata i da su najčešći aeroalergeni grinja kućne prašine Dermatophagoides pteronyssinus i poleni korova.

Više od polovine ispitanika je na alergološko testiranje upućeno zbog respiratorne alergije gornjih i donjih disajnih puteva, najviše zbog rinitisa. Rezultat je u skladu sa istraživanjima autora koji respiratornu alergiju, naročito rinitis, navode kao vodeći alergijski problem. ${ }^{6,7,15}$ Nalaz da je Dermatophagoides pteronyssinus vodeći alergen u svim ispitivanim grupama, naročito u grupi sa rinitisom, je u skladu sa rezultatima velikog broja sličnih istraživanja. ${ }^{9,8,16}$ Kada su u pitanju poleni, ustanovili smo da je najveći broj pozi- podatke i o manjem procentu preosjetljivosti na polene korova, ali su oni, uglavnom, na drugom mjestu po zastupljenosti iza polena trava. U pomenutim istraživanjima, kao i u našem, poleni drveća su po učestalosti iza polena trava i korova. ${ }^{13}$ Rezultati koje smo dobili istraživanjem pokazuju da je najmanji broj pozitivnih prick testova utrvrđen za bubašvabu, životinjsku dlaku i perje. Distribucija ovih alergena varira zavisno od geografske regije, klime i stambenih uslova pa su i literaturni podaci različiti. $\mathrm{U}$ dostupnim istraživanjima bubašvaba je navedena kao značajan alergen kod respiratorne alergije, naročito astme. ${ }^{10,20} \mathrm{U}$ Hrvatskoj, nama geografski bliskoj regiji, autori radova na ovu temu su došli do zaključka da je znatno niži postotak alergije na bubašvabu. ${ }^{21}$ Podaci o preosjetljivosti na alergene životinjske dlake, najčešće mačke i psa, takođe 
variraju u zavisnosti od geografske regije. ${ }^{30}$ Istraživanja koja su vršena pokazuju da jedna trećina ispitanika sa respiratornim smetnjama ima alergiju na dlaku mačke, dok je u multicentričnoj studiji iz Kine zapaženo da je značajan broj ispitanika alergičan na dlaku psa. ${ }^{13,22}$ Međutim, u radovima čiji su rezultati slični našim ispitivanjima, govori se o vrlo niskom procentu alergije na životinjsku dlaku. ${ }^{23}$

Značajan nalaz dobijen ovim istraživanjem je da je kod pacijenata muškog pola utvrđen veći broj pozitivnih reakcija na sve alergene, mada je u ukupnom uzorku bilo mnogo više žena nego muškaraca. Taj nalaz je u skladu sa rezultatima većeg broja radova. ${ }^{15,24,25}$ Studija u kojoj se zaključuje da je incidencija neatopijskog rinitisa u odrasloj dobi veća kod žena nego kod muškaraca, mogla bi objasniti naš nalaz da je testirano mnogo više žena nego muškaraca. ${ }^{26}$ Međutim, $\mathrm{u}$ nekim radovima nije nađena razlika u polnoj distribuciji. ${ }^{18}$

$\mathrm{Na}$ osnovu dobijenih rezultata proizlazi da pacijenti najčešce boluju od alergije gornjih respiratornih puteva, zatim kožne alergije, dok najmanji broj boluje od alergije donjeg respiratornog trakta. U ukupnom uzorku i po grupama bolesti najveći broj ispitanika je alergičan na Dermatophagoides pteronyssinus. Slijede poleni korova, trava, zatim drveća, dok je manji broj alergičan na dlaku, perje i bubašvabu. Najmanje jedan pozitivan alergen pokazao se kod 38,3\% ispitanika. U grupi ispitanika sa rinitisom je utvrđen veći broj pozitivnih reakcija na Dermatophagoides pteronyssinua, polene korova, trava i drveća nego u ostalim grupama. Mada je u desetogodišnjem periodu bilo više ispitanika ženskog pola, kod muškaraca je češce ustanovljena pozitivna reakcija na sve ispitivane alergene nego kod žena.

\section{Doprinos autora}

JB odgovorna za koncept, dizajn istraživanja, prikupljanje podataka, analizu, interpretaciju, pisanje prve verzije, korigovanih verzija i komunikaciju sa uredništvom časopisa. VG doprinijela prikupljanju podataka, njihovoj analizi i intepretaciji.

\section{Sukob interesa}

Autori su izjavili da ne postoji potencijalni sukob interesa.

\section{Reference}

1. Ring J. Allergy in practice. Berlin: Springer, 2005.

2. Schein C, Ivanciuc O, Midoro-Horiuti T, Goldblum R, Braun W. An Allergen Portrait Gallery: Representative structures and an overview of IgE binding surfaces. Bioinform Biol Insights 2010;4:113-25.

3. Platts-Mills TA, Woodfolk JA. Allergens and their role in the allergic immune response. Immunol Rev 2011;242:51-68

4. Jacquet $\mathrm{A}$. The role of the house dust mite-induced innate immunity in development of allergic response. Int Arch Allergy Immunol 2011;155:95-105.

5. Osterlund C, Grönlund H, Gafvelin G, Bucht A. Non-proteolytic aeroallergens from mites, cat and dog exert adjuvant-like activa- tion of bronchial epithelial cells. Int Arch Allergy Immunol 2011; 155:111-8.

6. Small P, Kim H. Allergic rhinitis. Allergy Asthma Clin Immunol 2011;7:3.

7. Pallasaho P, Rönmark E, Haahtela T, Sovijärvi AR, Lundbäck B. Degree and clinical relevance of sensitization to common allergens among adults: a population study in Helsinki, Finland. Clin Exp Allergy 2006; 36:503-9.

8. Valero A, Pereira C, Loureiro C, et al. Interrelationship between skin sensitization, rhinitis, and asthma in patients with allergic rhinitis: a study of Spain and Portugal. J Investig Allergol Clin Immunol2009;19:67-72.

9. Topal O, Erbek SS, Erbek S, Cakmak O. Epidemiological characteristics, distribution of allergens, and symptom severity in patients with perennial allergic rhinitis, living in Konya region. Kulak Burun Bogaz Ihtis Derg 2008; 18:227-31.

10. Ghaffari J, Khademloo M, Saffar MJ, Rafiei A, Masiha F. Hypersensitivity to house dust mite and cockroach is the most common allergy in north of Iran. Iran J Immunol 2010; 7:234-9.

11. Pallett D, Soh E, Edward ML, et al. Proof of concept pilot study: prevalence of grass virus infection and the potential for effects on the allergenic potency of pollen. Environ Health 2009; 8:S10.

12. Staikuniene J, Japertiene LM, Sakalauskas R. Influence of sensitation to pollen and food allergens on pollinosis clinical symptoms. Medicina (Kanuas) 2005;41:208-16.

13. Migueres M, Fontaine JF, Haddad T, et al. Characteristics of patients with respiratory allergy in France and factors influencing immunotherapy prescription: a prospective observational study (REALIS). Int J Immunopathol Pharmacol 2011;24:387-400.

14. Cvitanović S, Znaor Lj, Kanceljak-Macan B, Macan J, Gudelj I, Grbić D. Allergic Rhinitis and Asthma in Southern Croatia: Impact of sensitization to Ambrosia elatior. Croat Med J 2007; 48:68-75.

15. Voll-Aanerud M, Eagan T, Plana E, et al. Respiratory symptoms in adults are related to impaired quality of life, regardless of asthma and COPD: results from the European community respiratory health survey. Health Qual Life Outcomes 2010; 8:107.

16. Mahesh PA, Kummeling I, Amrutha DH, Vedanthan PK. Effect of area of residence on patterns of aeroallergen sensitization in atopic patients. Am J Rhinol Allergy 2010; 24:98-103.

17. D’Amato G, Cecchi L, Bonini S, et al. Allergenic pollen and pollen allergy in Europe. Allergy 2007; 62:976-90.

18. Kupryś-Lipińska I, Elgalal A, Kuna P. Skin prick test with inhaled allergens in the general population of Lodz province. Pneumonol Alergol Pol 2009;77:229-34

19. Aydin S, Hardal U, Atli H. An analysis of skin prick test reactions in allergic rhinitis patients in Istanbul, Turkey. Asian Pac J Allergy Immunol 2009; 27:19-25.

20. Mathur S. Allergy and asthma in the elderly. Semin Respir Crit Care Med 2010;31:578-95.

21. Macan J, Plavec D, Kanceljak B, Milkovic-Kraus S. Exositure levels and skin reactivity to German cockroach (Blatella germanica) in Croatia. Croat Med J2003;44:756-6o.

22. Li J, Sun B, Huang Y, et al. A multicentre study assessing the prevalence of sensitizations in patients with asthma and/or rhinitis in China Allergy 2009; 64:1083-92.

23. Raukas-Kivioja A, Raukas ES, Meren M, Loit Lundbäck B. Al- 
lergic sensitization to common airborne allergens among adults in Estonia. Int Arch Allergy Immunol 2007; 142:247.

24. Goldhahn K, Bockelbrink A, Nocon M, et al. Sex-specific differences in allergic sensitization to house dust mites: a meta-analysis. Ann Allergy Asthma Immunol 2009; 102:487-94.

25. Shaikh WA, Shaikh SW. Allergies in India: an analysis of 3389 patients attending an allergy clinic in Mumbai, India.J Indian Med Assoc 2008; 106:220-24.

26. Kurukulaaratchy RJ, Karmaus W, Arshad SH. Sex and atopy influences on the natural history of rhinitis. Curr Opin Allergy Clin Immunol 2012; 12:7-12.

\title{
Allergic Diseases of Patients Treated in the Clinical Centre Banjaluka: Results of Skin Prick Test in the Ten Year Period
}

\author{
Jagoda Balaban, Vesna Gajanin
}

\begin{abstract}
Introduction. Air borne allergens are the most common causes of allergy. They include pollens, house dust mites, animal hair and other animal products. Our study sought to determine which allergens were responsible for allergic diseases in patients seen at the Clinical Center Banjaluka from 2001-2010.

Methods. This retrospective population study included 4003 patients, late adolescents and adults. Most patients (63.5\%) were female. Their response to aeroallergens was assessed by skin prick tests.

Results. Patients were diagnosed most frequently with rhinitis (40.8\%) or dermatitis (27.6\%); $16.1 \%$ had different allergic diagnoses and $15.5 \%$ had asthma. More than a third of the cohort (38.3\%) responded positively to at least one allergen. The rhinitis group had the greatest number of positive skin prick tests for dust mite (Dermatophagoides pteronyssinus) (24.1\%) and weed pollens (18.3\%), grass pollens (15.2\%), and tree pollens (8.2\%). A small number of patients tested positive to animal hair (1.5\%), feathers (2.6) and cockroach (2.8\%) allergens. Those with other diagnoses were the least responsive. There were no statistically significant differences between groups tested for cockroach (Blatella germanica), feathers and animal hair._Although most patients were female, allergy is more common in men than in women.

Conclusion. More than one third of the patients tested had allergic rhinitis. House dust mite (Dermatophagoides pteronyssinus) and weed pollens were the most common aeroallegens for all tested groups.
\end{abstract}

\section{KEY WORDS}

aeroallergens, skin prick test, rhinitis, asthma, dermatitis 